\title{
FUNGSI TARI BARIS POLENG KETEKOK JAGO \\ DI DESA DARMASABA KABUPATEN BADUNG
}

\author{
Nyoman Triyana Usadhi \\ Jurusan Tari, Fakultas Seni Pertunjukan, Institut Seni Indonesia Yogyakarta \\ Email:manggus999@gmail.com
}

\begin{abstract}
RINGKASAN
Tari Baris Poleng Katekok Jago adalah tari tradisi Bali yang berbentuk komposisi tari kelompok dengan ciri berbaris, berderet, dan berjajar. Disebut Baris Poleng Ketekok Jago karena busana dan asesori yang dipakai didominasi oleh loreng "poleng" hitam dan putih. Dalam kehidupan beragama Hindu di Bali disebutkan ada tiga jenis kain poleng yakni: saput poleng rwabhineda, saput poleng sudamala, dan saput poleng tridatu. Aplikasi busana poleng dalam Baris Poleng Katekok Jago lebih didominasi oleh penggunaan poleng rwabineda dan poleng sudhamala. Poleng rwabineda berbentuk strip melintang sebagai hiasan pada desain kaki celana dan lengan baju; sedangkan poleng sudhamala menjadi hiasan pada saput seperti kain poleng tridatu, kain-kain kuno seperti cepuk, gringsing dan sejenisnya, menjadi hiasan tambahan yang kuat memberikan kesan angker dan kuno pada tampilan figur dari masing-masing penarinya. Hal-hal inilah yang menjadikan Baris Poleng Katekok Jago di Desa Tegal Darmasaba menjadi unik dan istimewa.
\end{abstract}

Dalam penelitian ini, antropologi menjadi ilmu untuk membedah masalah yang terjadi di dalam suatu kelompok masyarakat. Masyarakat pendukung memiliki hubungan erat dengan pemahaman mengenai fungsi suatu tari dalam upacara keagamaan. Tari Baris Poleng Katekok Jago sebagai produk kebudayaan yang terkait dengan ritual keagamaan Agama Hindu Bali. Fungsi sebagai kenyataan sosial yang harus dicari dalam hubungannya dengan tujuan sosial. Fungsi dari setiap bagian ialah memelihara hidup itu. Menurut Malinowski dan J. van Baal fungsi kebudayaan adalah harus memenuhi kebutuhan integratif, seperti agama dan kesenian. Dalam konsep rwabhineda sangat erat kaitannya dengan pemahaman Spiro bahwa fungsi menentangkan hubungan yang terjadi antara satu hal dengan hal lain dalam satu sistem yang terintegrasi. Fungsi integratif ini demikian melekat pada Tari Baris Poleng Katekok Jago dan agama Hindu Bali, sehingga sifat integratif ini melahirkan hubungan kedekatan antar religi dan kesenian yang oleh masyarakat Hindu Bali diekspresikan sebagai kewajiban manusia. 
Tari Baris Poleng Katekok Jago merupakan tari wali berfungsi sebagai tarian dalam upacara Pitra Yadnya dan Dewa Yadnya. Tari Baris ini menggunakan gerakan dan tata busana yang sederhana. Tari ini juga merupakan tari sakral yang digunakan pada upacara yadnya pada tingkatan Madya dan tingkatan Utama sebagai simbol dari kesatria yang mengawal turunnya Para Dewa ke bumi di setiap upacara Dewa Yadnya, seperti Karya Ngenteg Linggih, Karya Padudusan Agung, Karya Padudusan Alit dan sebagainya. Tari Baris Poleng Katekok Jago di desa Tegal Darmasaba dalam upacara Pitra Yadnya (ngaben), hanya diperuntukkan bagi kaum yang memiliki kasta (catur warna) tertinggi. Penari Baris Poleng Katekok Jago menjadi perajurit yang mengawal arwah menuju tujuan akhirnya.

\title{
Kata kunci: Tari Baris, tradisi, upacara adat, fungsi
}

\begin{abstract}
Baris Poleng Katekok Jago Dance in Tegal Darmasaba Village Badung Regency is a Balinese traditional dance in the form of dance group composition with character of marching, lined, and lined. Called Polis Katekok Jago caused by the dominance of the use of clothing and accessories black and white "poleng". In the Hindu life in Bali mentioned there are three types of poleng cloths: poleng rwabhineda cloth, poleng sudamala cloth, and poleng tridatu cloth. The type of poleng application in Baris Poleng Katekok Jago clothing is more dominated by the use of poleng rwabineda and poleng sudhamala. Rwabineda pods cross-shaped strips as decoration on the design of the pants leg and sleeve; while the sudhamala pans become a decoration on the membranes such as tridatu cloth, ancient fabrics such as cepuk, gringsing and the other kinds, to be a powerful additional decoration giving the impression of austere and old-fashioned appearance of each of the dancers. These are the things that make Baris Poleng Katekok Jago in Tegal Darmasaba Village become unique and special.
\end{abstract}

In this study, anthropology becomes the science to dissect the problems that occur within a community group. The support community has a close relationship with the understanding of the function of a dance in a religious ceremony. Baris Poleng Katekok Jago Dance as a cultural product associated with religious rituals Hindu Religion Bali. Function as a social reality to look for in relation to social goals. The function of each part is to maintain that life. According to Malinowski and J. van baal the function of culture is to meet the integrative needs, such as religion and art. In the concept of rwabhineda is closely related to Spiro's understanding that the 
function of opposing relationships takes place between one thing and another in an integrated system. This integrative function is so inherent in the Baris Poleng Katekok Jago dance and the Balinese Hindu religion, so this integrative character gives birth to the interrelationship between religion and art which by Balinese Hindu society is expressed as human obligation.

Tari Baris Poleng Katekok Jago dance is a guardian dance serves as a dance in the ceremony Pitra Yadnya and Dewa Yadnya. This line dance uses simple movements and clothing. Baris Poleng Katekok Jago dance is a sacred dance used in yadnya ceremony at the level of Madya and Utama level as a symbol of the knights who guard the descendants of the gods to the earth in every ceremony of the Dewa Yadnya, such as Ngenteg Linggih, Padudusan Agung, Padudusan Alit, and so on. Baris Poleng Katekok Jago dance in the village of Tegal Darmasaba in ceremony Pitra Yadnya (Ngaben), only for the people who have the highest caste (catur warna). Baris Poleng Katekok Jago became a soldier guarding the spirit toward its final destination.

\section{Keywords: Baris Dance, Tradition, Traditional Ceremony, Function}

\section{PENDAHULUAN}

Tari Baris yang dalam pementasannya memakai cara berbaris, berderet dan berjajar. Di Desa Tegal Darmasaba Kabupaten Badung terdapat sebuah tari Baris yang bernama Baris Poleng Katekok Jago. Nama "Baris Poleng" dikarenakan wujud tampilan tarian ini didominasi penggunaan busana dan aksesoris loreng "poleng" hitam dan putih. Dalam kehidupan beragama Hindu di Bali disebutkan terdapat tiga jenis kain poleng yakni: saput (jenis kain Bali) poleng rwa-bhineda, saput poleng sudamala, dan saput poleng tridatu. Saput poleng rwabineda adalah selembar kain dengan pola hias kotak-kotak dengan warna hitam putih; saput poleng sudhamala dihiasi oleh tiga warna yaitu hitam, putih dan peralihan warna hitam putih yakni abu-abu; sedangkan saput poleng tridatu berwarna hitam, putih dan merah. Aplikasi busana poleng dalam Baris Poleng Katekok Jago memang lebih didominasi oleh penggunaan poleng rwa-bineda dan poleng sudhamala. Poleng rwa-bineda berbentuk strip melintang dipakai sebagai hiasan pada desain kaki celana dan lengan baju; sedangkan poleng sudhamala menjadi hiasan pada saput seperti kain poleng tridatu, kain-kain kuno seperti cepuk, gringsing dan sejenisnya, menjadi hiasan tambahan yang kuat memberikan kesan angker dan kuno pada tampilan figur dari masing-masing penarinya Katekok Jago menjadi sebutan dari tari ini karena di dalam dramatisasi abstrak tariannya, 
mengandung gerak maknawi yang menirukan gerak gerik jenis unggas (ayam/jago) yang sedang bercinta pada musim birahinya, serta usaha mempertahankan generasi penerusnya dari ancaman musuh (gagak/elang). Jenis unggas (burung) dalam posisi pengider-ideran kebinatangan dalam kepercayaan Hindu diyakini sebagai penguasa spasial mandala belahan timur (purwa); sementara binatang berkaki empat diposisikan di selatan (daksina); binatang yang berjalan dengan dadanya berposisi di barat (pascima); sedangkan bangsa ikan yang merupakan binantang air berposisi di utara (utara). ${ }^{1}$ Hal ini tersirat dalam lontar majejiwan yang dilakukan ketika rangkaian upacara Nyenuk dalam salah satu rangkaian akhir dari sebuah upacara besar (Padudusan Alit/Agung, Ngateg Linggih, Resi Gana, Tawur Balik Sumpah dan tingkatan yang lebih tinggi) sebagai perlambang sidakarya, sidapurna dari penyelenggaraan sebuah yadnya. Keberkahan yang datang melimpah dari berbagai penjuru mata angin diperuntukkan bagi yang menyelenggarakan yadnya. Ditandai oleh pemakaian busana dengan variasi representasi kedudukan warna dalam pengider-ideran; membawa serta sesajen, hasil umbi-umbian dari tanah (palabungkah), dan hasil buah-buahan yang menggayut di pohon (palagantung), lengkap dengan masakan lauk pauknya. Para penari

1 I Nyoman Catra. 2007. Imba Penopengan Sidakarya. Denpasar: UPTD Taman, halaman $62-63$. disambut oleh Tokoh Topeng Sidakarya sebagai simbol penyelenggaraan sebuah upacara yadnya yang sukses. Para penari berinteraksi dengan Topeng Sidakarya memperkenalkan masing-masing diri dari mana asalnya, apa yang dibawa, lengkap dengan hewan yang disembelih untuk lauk pauknya. Kelompok tamu representasi dari Timur, akan menyebut datang dari Purwa Desa, membawa serta palabungkah, palagantung, serta masakan dari jenis unggas (iwak suku ro).

Purwa merupakan siklus perputaran planet, yaitu ketika matahari secara

kodrati terbit di ufuk timur. Timur dalam keyakinan umat Hindu menjadi tujuan

akhir perjalanan roh menuju
manunggaling atma
paramatma. Kata

parwa atau purwa berkaitan dengan asal muasal agama Hindu yang diyakini

sebagai jalan menuju tujuan akhir hidup. Keyakinan ini diwujudkan dalam

kehidupan setiap keluarga Hindu di Bali, masing-masing memiliki tempat suci

di dalam struktur pembangunan dan peletakan arah bagian-bagian rumah (pedum 
karang). Pada spasial timur laut setiap pekarangan rumah dibangun tempat suci

yang bernama Sanggah atau disebut juga Pemerajan. Sanggah atau Pemerajan

tersebut dilengkapi dengan bangunan suci yang disebut Sanggah Kemulan atau

Rong Tiga yang diposisikan di sebelah timur menghadap ke arah barat.

Sehubungan dengan arah timur, Tari Baris Poleng Katekok Jago diyakini sebagai

pengantar roh seseorang yang diupacarai menuju tujuan akhirnya ke alam asal,

yakni menuju arah Purwa atau kembali ke Kemulan.

Dibia dan Ruchina (2004: 81-82) mendeskripsikan Tari Baris Katekok

Jago dalam terjemahan bebasnya seperti berikut:

Salah satu bentuk yang paling menarik dalam

Baris Poleng Katekok Jago adalah, dipertunjukkan di kuburan dalam kaitan upacara kremasi (pelebon/pengabenan). Dua deretan penari mengenakan busana khusus kain poleng hitam putih menutupi pundaknya ibaratnya sayap, pertamanya menari bagaikan model militeristik (perajurit) membawa

\footnotetext{
2 I Wayan Dibia and Rucina Ballinger. 2004. Balinese Dance, Drama, and Music: Guide to the Performing Arts of Bali. Singapore: Periplus, halaman $81-82$.
}

senjata tombak. Kemudian penari paling depan dari barisan tersebut memulai mendatangi penari yang tengah, lalu berlutut secara bergantian dan menciumnya sembari mengepakkan sayapnya. Itu adalah salah satu dari gerakan yang mengharukan dalam tarian Bali ini, seakan ciumannya bagaikan ucapan perpisahan dengan atman (roh) mendiang. Gerakan ini sebenarnya menggambarkan seekor gagak yang mencuri telor dari sarang angsa, yang kemudian menyebabkan perang. ${ }^{2}$

Tari Baris ini membawa senjata berupa tombak dengan tangkai berukuran panjang juga dihiasi pontang hitam putih (poleng rwabineda) seperti halnya dominasi busananya. Jenis tarian ini merupakan perwatakan yang sangat unik, menekankan keseimbangan dan kestabilan langkahlangkah pada waktu berbaris maupun saat memainkan senjata sehingga disebut tari kepahlawanan. Simbol kepahlawanan dimaksudkan untuk membangun spirit kejuangan setiap individu dan masyarakat untuk saling menjaga fungsi sosial dalam spirit komunal masyarakat Hindu Bali.

Menurut J. van Baal menguktip Malinowski, fungsi sebagai "the part which is played by factor of a culture the general 
scheme" (bagian yang dimainkan oleh faktor budaya adalah skema umum), tetapi fungsi dapat dipahami sebagai "the functional theory of anthropology regards culture as an instrumental reality" (teori fungsional antropologi memandang budaya sebagai realitas instrumental), dan kemudian fungsi dipahami sebagai kewajiban untuk memenuhi kebutuhan hidup. Fungsi menjadi sesuatu yang melayani kehidupan dan kelanjutan hidup. Lebih lanjut dirumuskan, bahwa fungsi adalah sesuatu kenyataan sosial harus dicari dalam hubungannya dengan tujuan sosialnya. $^{3}$ Menurut pendapatnya, ada tiga tingkatan yang harus terekayasa dalam kebudayaan, yaitu: 1) kebudayaan harus memenuhi kebutuhan biologis, seperti kebutuhan akan pangan dan prokreasi, 2) kebudayaan harus memenuhi kebutuhan instrumental, seperti kebutuhan akan hukum dan pendidikan, dan 3). kebudayaan harus memenuhi kebutuhan integratif, seperti agama dan kesenian. ${ }^{4}$ Dalam konteks Tari Baris Poleng Katekok Jago dan agama Hindu Bali, bahwa fungsi integratif agama dan kesenian menjadi bagian penting dalam kehidupan masyarakat yang ditujukan untuk kelanjutan hidup

${ }^{3}$ J. Van Baal. 1988. Sejarah dan Pertumbuhan Teori Antropologi Budaya (hingga Dekade 1970). Jakarta: Gramedia, halaman 51.

${ }^{4}$ http://tikaaladawiyyah.blogspot.co.id/2017/03/broni slaw-malinowski-aspek-hukum.html diunduh tanggal 112 Oktober 2017 pukul 22.00 WIB. masyarakatnya. Makna penting fungsi inilah yang dijadikan acuan normatif dan keyakinan masyarakat Hindu Bali dalam mempertahankan identitas sosial budaya.

Menurut M.E. Spiro seperti dikutip oleh Koentjaraningrat, ada tiga cara pemakaian fungsi, yaitu: 1) fungsi itu sebagai hubungan guna antara sesuatu hal dengan sesuatu tujuan tertentu, 2) fungsi menerangkan korelasi antara satu hal dengan hal lain, 3) fungsi menentangkan hubungan yang terjadi antara satu hal dengan hal lain dalam satu sistem yang terintegrasi. ${ }^{5}$ Oleh karena itu, landasan pemikiran ini dan teori fungsionalisme Malinowski tentang fungsi kebudayaan untuk memenuhi kebutuhan integratif dapat dipakai untuk menganalisis hubungan antara agama Hindu Bali dengan Tari Baris Poleng Katekok Jago. Pemahaman Spiro mengenai fungsi bahwa hubungan antara satu hal dengan hal lain bertentangan dalam satu sistem integtasi sangat erat kaitannya dengan konsep rwabhineda. Kata poleng dalam Baris Poleng Katekok Jago merupakan simbolis dari rwabhineda. Fenomena hubungan fungsional ini merupakan bagian integral dari masyarakat Hindu Bali dari masa lampau dan masa kini.

\footnotetext{
5 Koentjaraningrat. 1985. Pengantar Ilmu Antropologi. Jakarta: Aksara Baru, halaman 213.
} 
II. FUNGSI TARI BARIS POLENG KETEKOK JAGO DI DESA DARMASABA KABUPATEN BADUNG

Fungsi tari Bali menurut hasil seminar seni sakral dan profan bidang tari yang diselenggarkan oleh Majelis Pertimbangan dan Pembinaan kebudayaan (Listibya) tahun 1971, diklasifikasikan ke dalam tiga tingkatan, yaitu seni tari wali, seni tari bebali, dan seni tari balih-balihan. Baris tergolong sebagai tari wali yang pada umumnya dipentaskan sebagai bagian yang tidak terpisahkan dari kegiatan upacara yang menyertai. Kendati disadari bahwa pengelompokkan ini tidaklah merupakan pemilihan yang kaku, namun lebih dipahami dari kontekstual, proses, dan keperuntukkannya. Hal ini menyebabkan tidak jarang satu jenis tarian akan dapat berfungsi ke dalam ketiga jenis ranah pilihan tersebut. ${ }^{6}$

Tari Baris Poleng Katekok Jago merupakan tari wali yang masih lestari di Desa Tegal Darmasaba, Badung. Masyarakat memiliki keyakinan yang kuat bahwa Ida Bethara Bethari yang beristana di Pura Dalem Kebon Buni memiliki kaitan taksu berkesenian yang dibuktikan dengan adanya benda-benda seni seperti topeng yang menjadi artefak di

\footnotetext{
${ }^{6}$ Nyoman Catra. 2007. Imba Penopengan Sidakarya.
} Denpasar: UPTD Taman, halaman 64. pura tersebut. Pada suatu masa kesenian ini pernah tidak dibangun yang kemudian menjadi gangguan untuk keselamatan desa. Kemunculan ancangan Ida Bethara yang berupa ular loreng (lipi poleng) sebagai sebuah tanda yang akhirnya diyakini bahwa fungsi kesenian Baris Poleng Katekok Jago tersebut merupakan tari wali pada upacara di Pura tersebut yang selalu hadir sebagai kesenian sakral bagian yang tidak terpisahkan dari piodalan. ${ }^{7}$ Hal inilah yang membuat kesenian ini masih ajeg dan lestari.

Terindikasi bahwa kesenian Baris Poleng Ketekok Jago umum dipahami oleh masyarakat adalah jenis Tari Baris untuk upacara Pitra Yadnya, juga berfungsi sebagai tari upacara Dewa Yadnya.

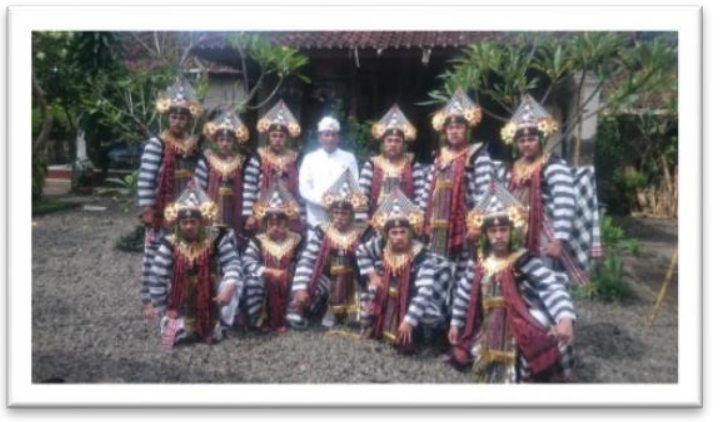

Gambar 5: Para penari Baris Poleng Katekok Jago saat sebelum menari bersama Anak Agung Sudharma. Bertempat di Darmasaba dalam upacara ngaben Ida Pedanda Made Gunung.(Foto: Nyoman Triyana Usadhi 2014)

\footnotetext{
${ }^{7}$ Wawancara, Adi Gunarta, 5 Februari 2018.
} 


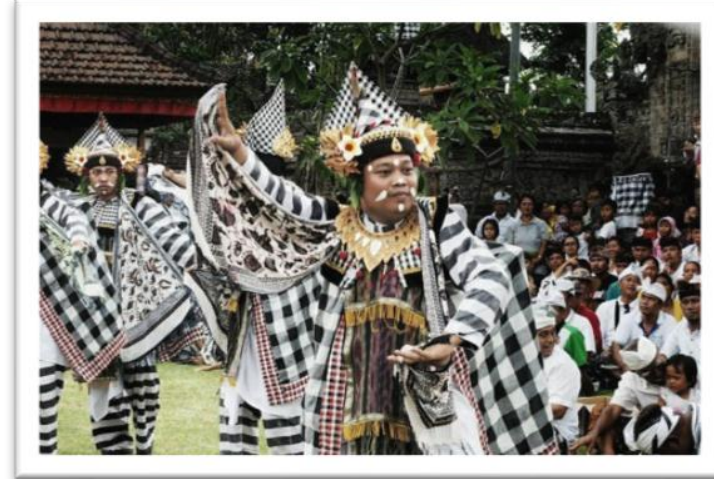

Gambar 6: Pose penari menarikan selendang cepuk Baris Poleng Katekok Jago di Pura Desa

Kapal. Masyarakat yang ikut serta dalam upacara piodalan menyaksikan tarian tersebut.

Terjadi berbagai reaksi dan ekspresi bagi masyarakat yang menyaksikan.

(Foto: Agung Ari 8 Agustus 2015)

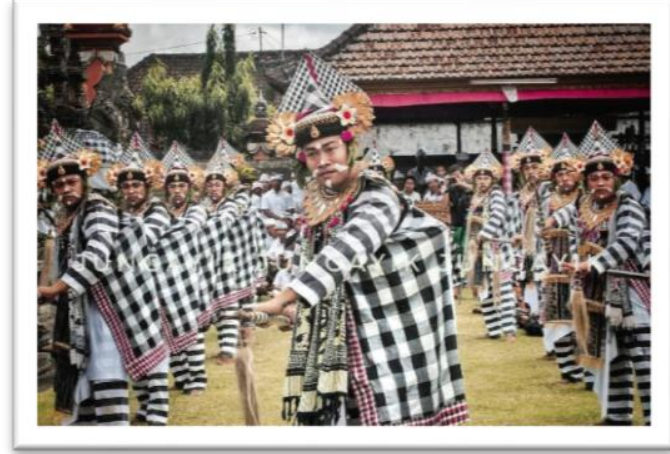

Gambar 7: Penari Baris Poleng Katekok Jago menari menghadap ke arah pelinggih. Di belakang penari tampak balè yang merupakan tempat pemain gamelan duduk dan mengiringi penari. Tampak dalam gambar sebuah papan dengan kertas yang merupakan catatan punia (sumbangan) yang diberikan oleh masyarakat kepada pura untuk melaksanakan piodalan.

(Foto: Agung Ari 8 Agustus 2015)

Sakralisasi (wali) adalah sangat kental dengan seni pertujukan yang berkaitan

\footnotetext{
${ }^{8}$ I Made Artana. 2015. "Tari Wali Baris Katekok Jago" dalam Kesenian Sakral: Tari Joged Pingitan dan Baris Upacara. Denpasar: Listibiya Provinsi Bali. Halaman 23.
}

dengan upacara dalam Agama Hindu. Ida Rsi Agung Wayasaba Supraba Sogata Karang mengarah pada pemikiran para budayawan cendekiawan di tahun 1970an yang melahirkan pengklasifikasian fungsi tari ke dalam katagori wali, bebali, dan balih-balihan. ${ }^{8}$ Pengklasifikasian tersebut, memformulasi kembali unsur-unsur yang menjadikan kesenian tersebut tergolong sakral (wali) adalah:

1. Kepercayaan / agama.

2. Peristiwa berkaitan dengan alam spiritual (bertanya, memohon petunjuk secara niskala)

3. Sarana upacara dan upakara dengan pelaksanaannya.

4. Ritual dengan mantra-japa mudra.

5. Mitos yang memberi landasan rasional bagi pelaksanaan ritual. Potensi naratif mitosnya banyak berperan sebagai bibit unggul timbulnya sebuah seni pertunjukan.

6. Lebih menekan pada motivasi ngayah dari motivasi lainnya (ekonomi)

7. Fungsi ritual lebih penting dari fungsi hiburan.

$$
\text { Dapat dielaborasikan bahwa }
$$

kesenian sakral (wali) tidak bisa dilepaskan dari tiga konteks yang terkait dalam kegiatan 
agama Hindu yakni: Dalam konteks ruang, potensi kesakralannya cenderung mengarah dan berada sekitar ruang suci, keramat, angker (tenget), dalam waktu-waktu transisi dalam hari.

1. Dalam konteks waktu, potensi sakral biasanya mengikuti sirkulasi sasih, wewarnan.

2. Dalam konteks peristiwa atau proses kegiatan yang sarat dengan nilai ritual seperti dalam pembuatan barong, gamelan, dan juga tarian sakral.

Iklim berkesenian di Bali tidak bisa dilepaskan dari proses sakralisasi tersebut. Karya seni kendatipun yang dibangun merupakan sebuah kesenian baru (kontemporer), namun dari mulai latihan, banten penunasica tetap dihadirkan demi kelancaran proses penggarapan. Ini menjadi bagian dari berkesenian di tanah pulau seribu pura, terlebih lagi kesenian yang memang diperuntukkan dengan tujuan sakral (wali). Prosesnya dari awal sampai dengan mejaya-jaya, mlaspas, pasupati, adalah rentetan proses penyatuan spektrum alam sekala dan niskala. Sebuah kesenian manakala dipentaskan untuk kaitan upacara yadnya ritualnya menjadi utama menyertai sebelum kegiatan menari dilaksanakan.
Kegiatan upacara yadnya yang dilakukan oleh umat Hindu dari kelima domain yadnya dalam kelompok Panca Yadnya, upacara pengabenan/palebon tergolong ke dalam upacara Pitra Yadnya. Bagi umat Hindu upacara ini juga memiliki tingkat penyuciannya di antaranya: pembakaran jasad/jenasah (badan wadah) seseorang yang sudah meninggal dengan upacara ngaben; kemudian pada tingkatan keduanya dilakukan upacara mamukur yang memiliki arti dan makna penyucian roh (sanghyang atma) sebagai unsur jiwa yang tak kasat mata.

Upacara nyegaragunung dilakukan setelah itu, yang memiliki makna sebagai penyatuan alam raya bhuana agung dalam manisfestasi perjalanan roh menghadap Hyang Maha Kuasa. Pada bagian terakhir baru dilakukan upacara ngunggahang, yakni penyucian, sudah ditingkatkan statusnya menjadi dewapitara, Rong Tiga/Kemulan. Dari tempat ini interaksi generasi yang ditinggalkan dengan mereka yang sudah disucikan (leluhur) dapat dilakukan dengan berbagai upacara baik dalam bentuk persembahan yadnya secara rutin (nitya karma) ataupun upacara yadnya yang (naimitika karma), sebagai wujud interaksi berkesinambungan dalam menghormati para leluhur. $^{9}$

\footnotetext{
${ }^{9}$ Nyoman Catra. 2007. Imba Penopengan Sidakarya. Denpasar: UPTD Taman, halaman 68.
} 
Dalam praktiknya, agama Hindu mengajarkan umatnya untuk melakukan upacara persembahan. Persembahan ini mengedepankan fleksibilitas dengan kelenturan dalam ketulusikhlasan menghaturkan persembahan ke dalam tingkatan: kanista, madyama, dan mahotama. Esensi dasar dari bentuk sebuah persembahan tetap diutamakan, dan tidak dibatasi untuk memberikan bentuk sajian persembahan yang lebih besar, lengkap, dan megah sesuai dengan kemampuan ekonomi, tujuan, serta keinginan yang melaksanakan upacara yadnya.

\section{A. Perlengkapan Busana dan Aksesoris}

Nuansa poleng sangat kuat mendominasi tampilan figur seorang penari Baris Poleng Katekok Jago. Terlebih lagi manakala para penari menari bersama, kekuatan loreng hitam putih dengan gradasi warna abu-abu di antaranya menjadikan tarian ini sungguh merupakan Tari Baris Poleng yang memiliki daya berkarakteristik magis.

Busana yang dikenakan oleh masingmasing penari terdiri dari:

1. Celana panjang loreng strip hitam putih melingkar di bagian bawah pergelangan kaki sampai di atas lutut (poleng rwabhineda).

2. Baju loreng strip melingkar pada lengan bajunya (poleng rwa-bhineda); namun tidak jarang penari Baris Poleng
Katekok Jago menggunakan kain poleng sudamala untuk baju maupun celananya.

3. Kain kancut putih (seperti lazimnya dipakai oleh kebanyakan jenis tarian Baris pada umumnya).

4. Menggunakan saput loreng (poleng sudamala) yang pada pinggirannya dihiasi eled hiasan tepi yang terbelah pada bagian depan.

5. Memakai seselet berupa senjata keris sebagai simbolis purusa.

6. Memakai gelungan (mahkota) berupa gelungan Baris yang ditandai dengan udeng-udengan berbentuk segitiga pada bagian belakang, sementara di atasnya memakai kojong loreng (poleng sudamala) serta dihiasi dengan bunga.

7. Berbagai varian kain tenunan lelawasan digantung mengguyat melingkar leher berfungsi sebagai awiran.

8. Selembar kain menutupi pundak (angkeb pala), yang pada bagian dramatisasinya dipakai sebagai representasi sayap burung.

9. Jempongan bunga kemerakan dilengkapi daun gegirang sebagai hiasan telinga penari.

10. Tombak yang tangkaiannya dipotong poleng (rwa-bhineda)

11. Rias wajah biasanya hanya menggunakan gecek atau olesan pamor 
putih (kapur sirih) yang dipakai sebagai hiasan make-up. Pamor putih tersebut dipercayai sebagai simbol perlindungan untuk penari yang mengoleskannya pada wajah. Bentuk riasan dari olesan pamor putih tersebut menyerupai karakter orang tua yang rambutnya telah berubah menjadi putih. Warna putih juga merupakan refleksi warna dari timur yang diwakili dengan burung. Dapat dikatakan bahwa riasan wajah Baris Poleng Katekok Jago berkaitan dengan bentuk bulu dari burung tersebut. Tiga gecek yang dipasang di antara alis kiri dan kanan serta di samping luar kedua alis merupakan simbol keseimbangan.

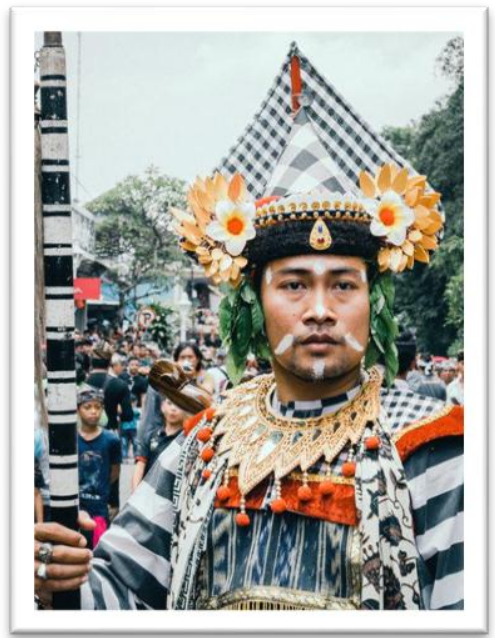

Gambar 3: Rias Baris Poleng Katekok Jago. (Foto: Putu Anggradana 8 Agustus 2015)

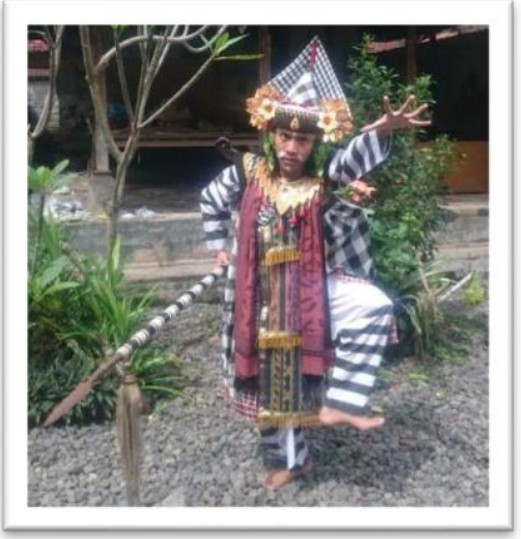

Gambar 4: Busana Baris Poleng Ketekok Jago.

(Foto: Nyoman Triyana Usadhi 2014)

\section{B. Upacara dan Upakara}

Tari Baris Poleng Ketekok Jago merupakan tarian yang berfungsi sebagai tari wali, sehingga pementasannya tidak luput dari kelengkapan sesaji yang dihaturkan jelang pementasannya. Para penari sebelum menari melakukan persembahyangan (penunas ican) guna mendapatkan keselamatan dan kesuksesan dalam swadharna saat pentas nantinya. Umum berlaku pada tradisi kesenian dalam kaitannya dengan upakara yandnya adalah dengan adanya banten pengeloman. Banten sebagai pengingat dan sarana untuk memastikan bahwa permohonan untuk nuwur jenis kesenian yang disertai dalam upacara yang disebut banten penueuran. Seniman dalang cenderung lebih kompleks aturan banten yang diruntut sesuai dharma pewayangan bertautan dengan ritual yang 
harus dilakukan sebagai seorang seniman.

Melalui upakara banten yang disajikan sebagai sarana untuk permohonan ke hadapan Hyang Taksu, seniman memohon ke hadapan Sang Maha Pencipta guna mendapatkan kelancaran dan kesuksesan dalam menjalankan profesinya sebagai seniman.

Upakara yang dibutuhkan guna menunjang keberhasilan pementasan Tari Baris Poleng Katekok Jago, di antaranya adalah:

\section{Banten Peras Gede dengan daksina lima} buah.

2. Banten Peras cenik pejati satu soroh.

3. Banten Naso rongan lima punjung.

4. Be karangan satu karang.

5. Ayam pitik untuk penyamblehan (proses sembelih).

6. Banten segehan mancawarna lima tanding.

7. Banten segehan putih dan kuning sepuluh tanding.

8. Banten pasucian satu soroh.

9. Uang tapis (pis bolong)

10. Banten rantasa putih kuning.

\section{PENUTUP}

Asal mula tari Baris Katekok Jago yang berada di Desa Adat Tegal, Darmasaba adalah warisan budaya lokal yang sudah ada sejak tahun 1927, bertempat di Pura Dalem Gegelang atas prakarsa "sekeha majukut" kelompok tani pimpinan I Ngilis (Alm) dan hingga saat ini masih tetap dilestarikan oleh generasi penerus masyarakat desa Adat Tegal, Darmasaba. Fungsi tari Baris Katekok Jago di Desa Adat Tegal, Darmasaba yaitu sebagai Tari Wali yang ditarikan sebagai pengiring disetiap upacara Dewa Yadnya dan upacara Pitra Yadnya (ngaben/palebon) khususnya di Desa Adat Tegal Darmasaba. Tarian Baris Katekok Jago lebih mementingkan fungsinya, hal ini terlihat dari gerakan dan tata busana yang sederhana. Tari Baris Katekok Jago merupakan tari sakral yang digunakan pada upacara yadnya pada tingkatan Madya dan tingkatan Utama sebagai simbol dari kesatria yang mengawal turunnya para Dewa ke bumi. Seperti dalam Karya Ngenteg Linggih, Karya Padudusan Agung, Karya Padudusan Alit dan sebagainya dan mengawal arwah menuju tempatnya pada upacara Pitra Yadnya (Ngaben) khususnya di Desa Adat Tegal Darmasaba.

Dalam penyelengaraan upacara dari berbagai domain panca yadnya yang digelar, unsur-unsur yang harus melengkapai sebuah upacara yakni berupa bebagai persembahan. Persembahan tersebut terdiri dari: tempat 
JOGED

ISSN: 1858-3989

upacara yang dihias dengan segala keindahannya, banten (berbagai upakara dengan segala pirantinya), gita shanti (nyanyian upacara), seni pertunjukan tari, dan tabuh (gamelan), serta puja stawa pendeta/ pinandita, dalam struktur ilen-ilen yang runtut sesuai aturan. Dalam penyelenggaraan tersebut fleksibel sifatnya disesuaikan dengan kemampuan, mengarah pada konsepsi persembahan dalam tingkatan: kanista, madyama, dan mahotama. Hal ini dilandasi pada ketulusan dan keikhlasan sang adruwe karya (yajamana karya) yang selalu mengusahakan yang terbaik untuk persembahan, demi pemenuhan rasa puas tulus baktinya beryadnya.

Kehadiran Tari Baris Poleng Katekok Jago di dalam sebuah upacara pitra yadnya dalam tingkatan besar (baligya/ pengabenan) yang bermakna sebagai pengantar roh menuju tujuan akhir perjalanan panjang sanghyang atma, sifat pementasannya sesungguhnya mengingatkan kepada umat manusia yang masih hidup. Makna filosofis, pesan moral dan penyadaran diri terhadap hakikat hidup, yang tergambar pada dominasi nuansa poleng. Hal ini merupakan pemahaman yang mesti direnungkan lebih dalam, guna memperoleh arti dan makna hidup di kehidupan ini. Hidup rukun dalam keluarga dilandasi dengan penuh cinta dan kasih sayang, menjaga
Nyoman Triyana I Usadhi FUNGSI TARI BARIS POLENG OK JAGO DI DESA DARMASABA KABUPATEN BADUNG

keberlangsungan keturunan, memproteksi diri dari ancaman kehidupan, memiliki sifat purusa sebagai tujuan hidup dalam kehidupan. Semua itu mengisyaratkan kepada semua umat manusia dalam menjalani hidup di kehidupan ini. Pendidikan moral, pemahaman diri, menyadari bahwa tidak ada yang pasti secara terang benderang dalam menyikapi hidup ini. Inilah pembelajaran yang tersirat dan dapat dipetik dari tontonan Tari Baris Poleng Katekok Jago tersebut.

\section{DAFTAR SUMBER ACUAN}

\section{A. Sumber Tertulis}

Artana, I Made. 2015. "Tari Wali Baris Katekok Jago" dalam Kesenian Sakral: Tari Joged Pingitan dan Baris Upacara. Denpasar: Listibiya Provinsi Bali.

Baal, J van. 1988. Sejarah dan Pertumbuhan Teori Antropologi Budaya (hingga Dekade 1970). Jakarta: Gramedia.

Bandem, I Made. 1976. The Baris Dance. Denpasar, Bali: Serba Guna Press

Bandem, I Made dan Fedrick Eugene deBour. 2004. Kaja dan Kelod Tarian Bali Dalam Transisi. Yogyakarta: Badan Penerbit ISI Yogyakarta.

Bandem, I Made, I Nyoman Catra, dan N.L.N Suasthi Widjaja Bandem. 2016. 
Tari Baris Cina dan Tari Baris Poleng Ketekok Jago di Kota Denpasar.

Denpasar: Dinas Kebudayaan Kota Denpasar.

Catra, I Nyoman. 2007. Imba Penopengan Sidakarya. Denpasar: UPTD Taman Budaya Denpasar - Dinas Kebudayaan Provinsi Bali.

Catra, I Nyoman. 2015. "Tinjauan Aspek Seni Joged Pingitan dan Baris Upacara" dalam Kesenian Sakral: Tari Joged Pingitan dan Baris Upacara. Denpasar: Listibiya Provinsi Bali.

Dibia, I Wayan and Rucina Ballinger. 2004. Balinese Dance, Drama and Music:

Guide to the Performing Arts of Bali. Singapore: Periplus

Hadi, Y. Sumandiyo. 2006. Seni dalam Ritual Agama.Yogyakarta. Buku Pustaka

Hadi, Y. Sumandiyo. 2007. Kajian

$$
\text { Teks dan Konteks. }
$$

Yogyakarta: Pustaka Book

Publisher.

Koentjaraningrat. 1985. Pengantar Ilmu Antropologi, Jakarta: Aksara Baru.
Martono, Hendro. 2014. Koreografi

Lingkungan. Yogyakarta: Multi Grafindo

Rupawan, I Ketut. 2008. Saput Poleng dalam Kehidupan Beragama Hindu di Bali. Denpasar: P.T. Offset Bali.

Sumaryono. 2017. Antropologi Tari dalam Perspektif Indonesia. Yogyakarta:

Media Kreativas.

Suryabrata, Sumadi. 2006. Metodologi Penelitian. Jakarta: P.T. Raja Grafindo Persada.

\section{B. Narasumber}

A.A. Ayu Kusuma Arini selaku dosen ISI Denpasar dan seniman tari di desa Darmasaba.

Made Adi Gunarta selaku dosen ISI Denpasar dan penari Baris Poleng Ketekok Jago.

Anom Adnyana selaku penari Baris Poleng Ketekok Jago. 
JOGED

ISSN: 1858-3989

Nyoman Triyana I Usadhi FUNGSI TARI BARIS POLENG KETEKOK JAGO DI DESA DARMASABA KABUPATEN BADUNG

\section{Webtografi}

https://panbelog.wordpress.com/2015/02/15

/tari-baris-katekok-jago/

https://raseswara.wordpress.com/2010/01/0

9/tari-baris-tekok-jago-di-desa-

tegal-darmasaba/

http://tikaaladawiyyah.blogspot.co.id/2017/ 03/bronislaw-malinowski-aspek-

hukum.html

https://iputuadisaputrablog.wordpress.com/ 2016/12/21/tari-baris-katekok-jago-di-desaadat-tegal-darmasaba-bali/

https://raseswara.wordpress.com/2010/01/0 9/tari-baris-tekok-jago-di-desa-

tegal-darmasaba/ 